FACTA UNIVERSITATIS

Series: Economics and Organization Vol. 14, N ${ }^{\mathrm{o}} 2$, 2017,pp. $105-115$

DOI: $10.22190 /$ FUEO1702105M

Preliminary Communication

\title{
MACROECONOMIC DETERMINANTS OF ECONOMIC GROWTH IN SERBIA
}

UDC 330.101.541:330.55(497.11)

\author{
Ivan Milenković, Branimir Kalaš, Jelena Andrašić \\ University of Novi Sad, Faculty of Economics Subotica, Serbia
}

\begin{abstract}
Monetary policy is an important segment of the economic policy of each country where inflation and monetary aggregates represent its significant components. Their movement reflects the trends in the volume of money and the price level which is of great relevance for the economic situation in the country. The aim of the paper is to manifest the impact of macroeconomic indicators on the real gross domestic product. In this paper, inflation (INF), monetary aggregate (M3), public expenditures (PE) and foreign direct investment (FDI) are used as independent variables, while the gross domestic product is determined as a dependent variable. The results showed that there is a positive relationship between GDP and INF, PE and FDI, but it is statistically not significant. On the other hand, M3 has a negative impact on GDP, it is statistically significant. Using correlation matrix, a very high correlation between INF and PE was found, while the lowest correlation was recorded between GDP and INF.
\end{abstract}

Key words: gross domestic product, inflation, monetary aggregate, public expenditures, foreign direct investment, Serbia

JEL Classification: C10, E52, E60, H50

\section{INTRODUCTION - THEORETICAL BACKGROUND}

Inflation represents one of the most important phenomena in the economy. Since the 1970 inflation was not considered as a threat to the economy and Phillips (1987) showed in his empirical study that inflation has a positive reaction to economic growth and it is negatively related to unemployment. Snowdon and Vane (2005) concluded that this world economic condition survived only until 1970. For this period, Friedman (1976) defined

Received February 24, 2017 / Revised April 19, 2017/ Accepted April 26, 2017

Corresponding author: Branimir Kalaš

University of Novi Sad, Faculty of Economics Subotica, Serbia

E-mail: branimir.kalas@ef.uns.ac.rs 
that countries with high rates of inflation had lower rates of growth and determined the fact that high level of inflation is negatively related to growth. Further, Friedman and Schwartz (1963) argued that changes in money stock preceded changes in nominal income in the United States. The relationship between inflation and economic growth is one of the most popular macroeconomic issues among policy makers, central bankers, and macroeconomists (Barro, 1995).

There are many studies which researched linkage between inflation and economic growth (Barro, 1995; Ghosh and Phillips, 1998; Harris et al. 2001; Khan and Senhadji, 2001; Gokal and Hani, 2004; Mubarik, 2005; Lee and Wong, 2005; Saaed, 2007; Munir and Mansur, 2009; Quartey, 2010; John et al. 2011; Hasanov, 2011; Hossain et al. 2012; Kremer et al. 2012; Antwi et al. 2013; Shuaib et al. 2015; Ibarra and Trupkin, 2015; Ruzima and Veerachamy, 2016).

Ghosh and Phillips (1998) found a statistically significant negative relationship between inflation and economic growth, but their results showed that there can be a positive relationship between these variables when the inflation rate is ranged between 2-3 percent or below. Also, Harris et al. (2001) determined negative relationship using panel data for OECD and APEC countries from 1961-1997. Gokal and Hani (2004) used correlation matrix and Granger causality test for Fiji in the period 1970-2003 and found a weak negative correlation between inflation and economic growth and one-way causality which runs from growth to inflation. In his analysis, Quartey (2010) used Cointegration tests, Error correction model and Laffer curve on example of Ghana and determined that inflation has a negative effect on economic growth and it is maximized when the inflation rate is at $22.2 \%$. Malik and Chowdhury (2001) found a positive and statistically significant relationship between inflation and economic growth as well as that the sensitivity of growth to changes in inflation rates was smaller than that of inflation to changes in growth rates. On the other hand, Dotsey and Sarte (2000) studied the effects of inflation variability on economic growth for the United States and they found a negative relationship between these variables. Also, Lupu (2012) developed a model for the period 1990-2009 in Romania where the two decades are analyzed separately. In the first period, high and volatile inflation was the main source of macroeconomic instability that led to the GDP decrease. From 2001 to 2009 Romania had higher economic growth which it accompanied by a lower level of inflation. The same results, Boyd and Champ (2006) argued in their analysis where higher inflation leads to lower economic growth and lower inflation encourages economic growth. Erbaykal and Okuyan (2008) researched this relationship in Turkey using quarterly time series data from 1987-2006. Results of their analysis reflect no statistically significant long-term relationship and statistically significant short-term relationship. Ihsan and Anjum (2015) found that consumer price index and interest rate have a significant impact on GDP, where inflation rate has no significant impact on GDP. Khan and Senhadji (2001) found a statistically significant long-run negative relationship between consumer price index and real gross domestic product. Polan and Grauwe (2005) determined that positive reaction of real output on money supply growth could only be realised in the short run. In an analysis of 125 countries in the period 1980-2004, Abott and De Vita (2011) looked at this relationship in different exchange rate regimes. Their results showed that developing countries with adopted flexible exchange rate have higher and significant costs of inflation on the economic growth compared to countries which use fixed or intermediate exchange rates. 
Furtula (2007) emphasizes that central banks use different monetary instruments to achieve the ultimate objectives of monetary policy. Precisely their implementation or combination depending on their design, can be influenced by the amount of the money supply and thus provide an optimal economic development viewed from the standpoint of stability and economic growth.

On the other hand, Labus (2011) points out that the effects of monetary policy are reflected in the volume of money in circulation and in this sense monetary policy is politics of money. However, money supply and its growth rate is not the aim of monetary policy and not used for the assessment of its effects on production and level of prices and thus builds on the determination of monetary policy as a policy without money (Beck and Wieland, 2010). The concept of money supply should be positioned so that it is optimized for the national economy to function normally.

In contemporary conditions, the term of money supply includes the sum of financial forms which are considered as money in the economy of one country while the monetary aggregates used as a generic term for the different groups of financial instruments, money, and other financial assets. Monetary indicators are parameters that are affected by the central bank and they have the purpose of measuring the functioning of monetary policy (Hadžić, Barjaktarović, 2015).

\section{DATA AND ANALYSIS}

This segment of the paper reflects the movement of the annual growth rate of real gross domestic product and inflation and monetary aggregates as the main monetary indicators as well as government expenditures and foreign direct investment for the fifteen year period 2001-2015. Before statistic analysis of this variables, it is necessary to show their movement and level of growth rates.

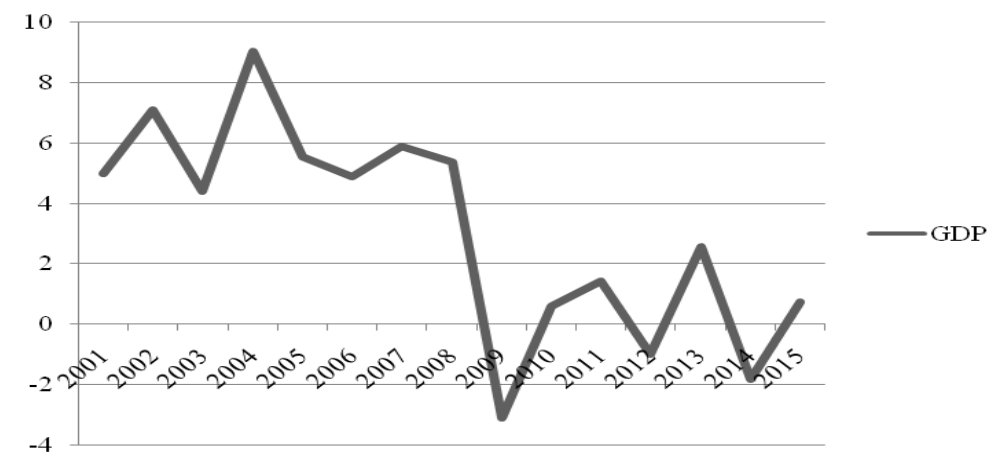

Fig. 1 The trend of GDP in Serbia from 2001 to 2015 Source: National Bank of Serbia

Based on Figure 1, it can be concluded that Serbia had high growth rates until 2008 after which there is a steep decline in 2009 , when it stood at $-3.8 \%$. In the pre-crisis, this growth can be attributed to the inflow of foreign capital which is drawn through the process of privatization 
in Serbia. However, after the slowdown of the global economy in 2008 and especially in 2009, there was a decline in the level of foreign direct investment in the world which is reflected on Serbia.

Bearing in the mind that growth of Serbian economy is dependent on foreign capital, Serbia uses an aggressive policy of attracting foreign direct investment by providing subsidies. In this way, it has managed to attract no small number of investors, including the Fiat and their components whose production and export directly reflected in the growth rate of the gross domestic product. At the end of 2015, Serbia had a modest growth of $0.74 \%$ which is far from the level that is required for the dynamic growth of our economy.

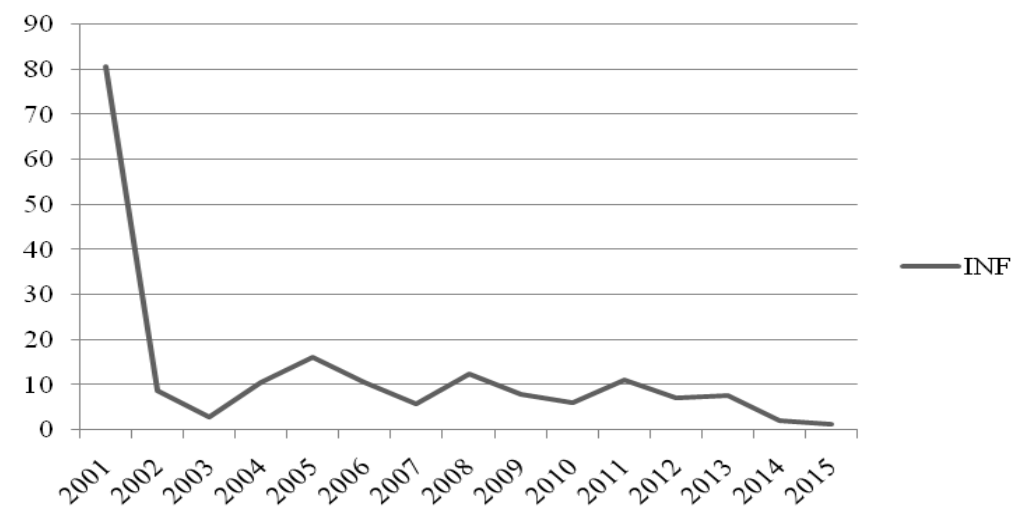

Fig. 2 The trend of inflation in Serbia from 2001 to 2015 Source: National Bank of Serbia

Figure 2 reflects the annual growth rate of inflation in Serbia for the period 20012015. At the beginning, the average inflation rate stood at over $80 \%$ and then the tenfold fall occurred in 2002 and 2003 when inflation was at the level of $2.71 \%$. Next, in the period 2004-2008, the growth of inflation was higher than the growth of the GDP which implies that prices in Serbia increased faster than gross domestic product. This can especially be seen in 2005 when the inflation growth was three times higher than GDP growth or $16.25 \%$ compared to $5.54 \%$. In 2011 a high inflation rate of $11.74 \%$, was recorded, but in the coming years, inflation had slight decrease trend. However, looking at the previous two years and especially 2015, inflationary pressures remained low on the basis that the majority of domestic factors , as well as on the basis of low prices of primary products (oil and agricultural commodity products) on the world market and generally low inflation in the international environment (National Bank of Serbia, 2015). In 2015, the economy had the lowest inflation rate of $1.39 \%$ which is over $98 \%$ less compared to the beginning of the observed period. 


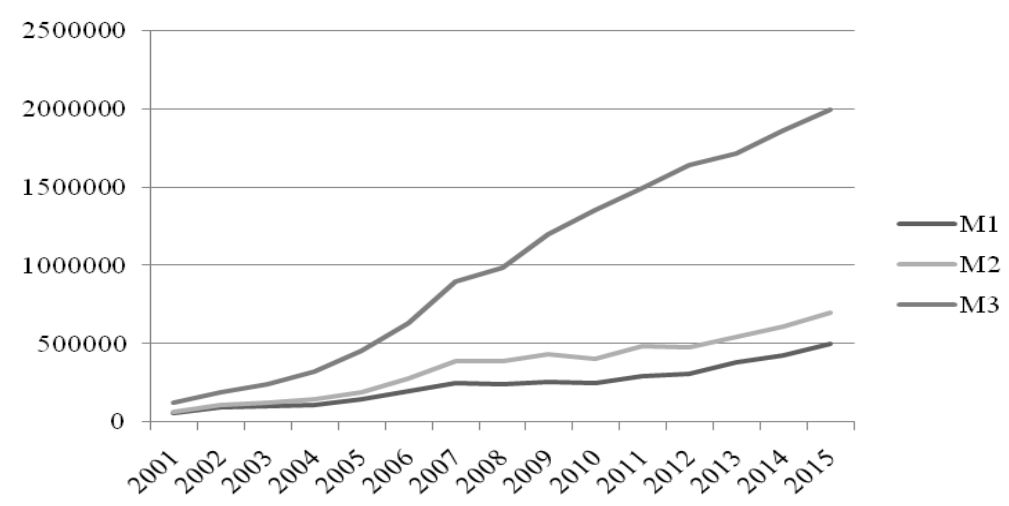

Fig. 3 The trend of monetary aggregates in Serbia from 2001 to 2015 Source: Ministry of Finance

Looking at the movement of monetary aggregates in Serbia, their growing tendency can be noted. What is noticeable that all indicators have recorded the highest growth rates in 2001 when there has been an increase of over $90 \%$ of M3 and more than $100 \%$ of M1 and M2 at the annual level. A similar trend was recorded in the next year where the growth of indicators ranged 50-60\%. In the period 2003-2007, M3 increased faster than the previous two indicators and its average growth rate was $36.52 \%$ which is $14.4 \%$ more than M1 and $26.7 \%$ compared to M2. This can be attributed to positive growth rates of M3 during the whole observed period, unlike M1 and M2 which had negative growth rates. M1 had negative growth rates in 2008 and 2010 where it amounted to $3.3 \%$ and $2 \%$, while on the other hand, M2 declined in 2010 and 2012 when rates were negative of $6 \%$ and $1.5 \%$. However, in the last four years, M1 had the highest average growth rate of $14.75 \%$ compared to M2 and M3 whose average growth was around 7\% and $9 \%$.

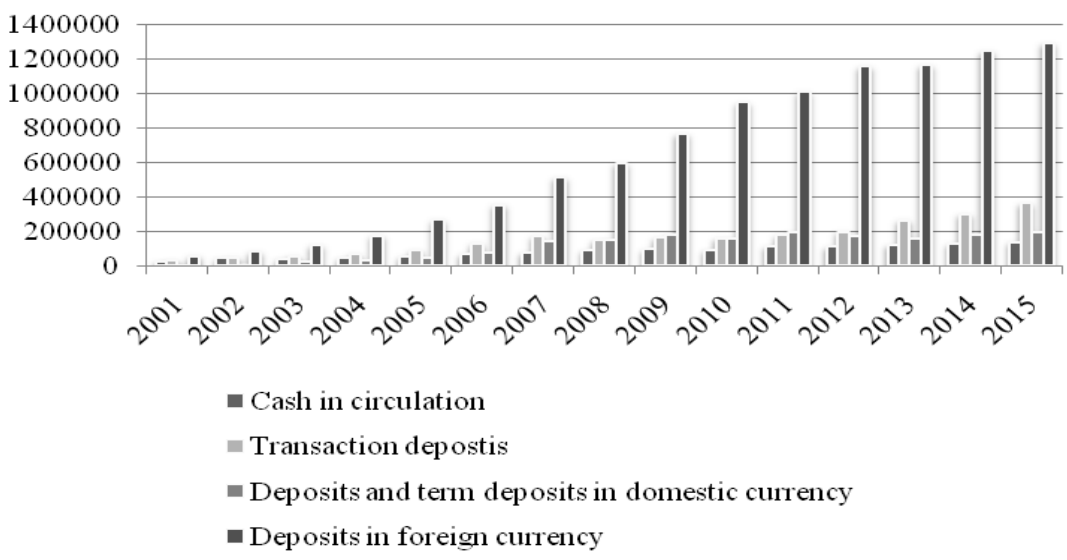

Fig. 4 Components of monetary aggregates in Serbia from 2001 to 2015 Source: Ministry of Finance 
Following the previous figure, components of monetary aggregates for the same period were observed. First, as part of M1, both categories have growing trend during all years except 2010 and 2012, at cash in circulation and 2008 at transaction deposits which coincide with negative rates of M1. Second, deposits in domestic currency and term deposits have a growing trend except in 2010 and 2012, which is identical with the declining trend of M2, but it is indicative that in 2013 a declining trend in this category was recorded although it did not affect the observed monetary aggregate. On the other hand, deposits in foreign currency recorded the constant growth which shows greater confidence in the foreign currency compared to domestic currency. Also, in the last five years, the average growth of deposit in foreign currency amounted to $28.45 \%$ where in 2006 it recorded the highest growth rate of $44.41 \%$.

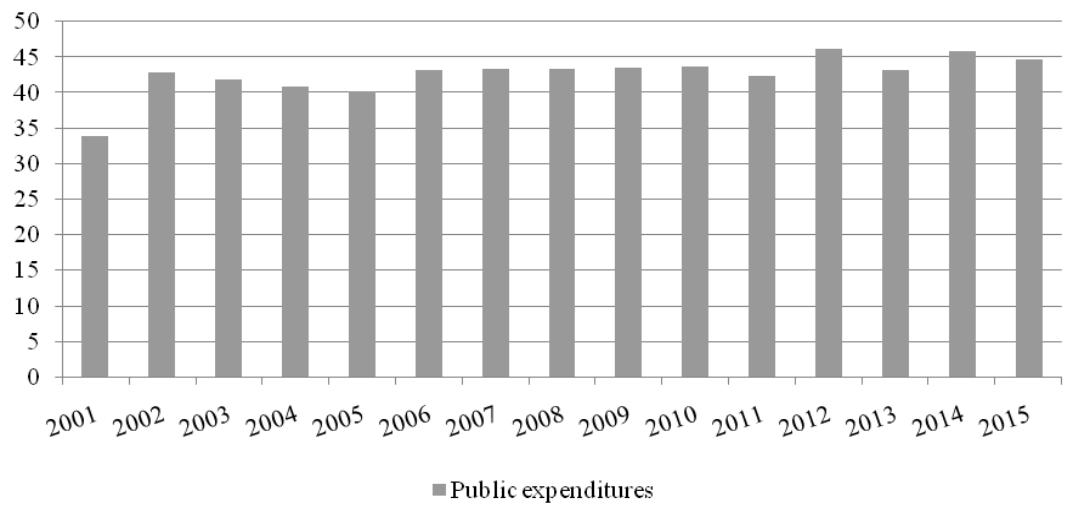

Fig. 5 The trend of public expenditures in Serbia from 2001 to 2015 Source: International Monetary Fund

It is necessary to reflect the share of public expenditures in GDP and their trend because this variable is included in the model. The average share of this indicator in GDP amounts to $42.61 \%$. In 2001, it amounted to $33.81 \%$ in order for the next year there was an increase of $9.09 \%$. A similar trend was recorded in 2006 and 2012. when the share increased by $2.92 \%$ and $3.74 \%$. From 2012, public expenditures have a decreasing trend, where it was $44.74 \%$ in 2015.

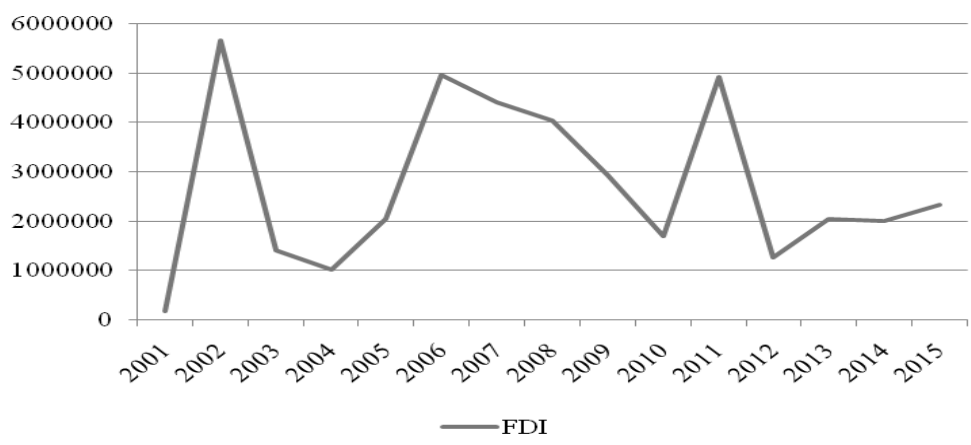

Fig. 6 Foreign direct investment in Serbia from 2001 to 2015 Source: Trading Economics 
Figure 6 manifests the level of foreign direct investments in Serbia in the period 20012015. The highest level of FDI was recorded from 2006 to 2008 when the average level of foreign capital was 4.482 billion dollars. Since 2008, foreign direct investments are reduced as a result of decreasing foreign investments at the global level, which can be attributed to the economic crisis in the US and EU. At the end of 2015, FDI was 2.347 billion dollars which is almost double less compared to the pre-crisis period.

\section{MeTHODOLOGY}

The aim of this paper is to find out the nexus between macroeconomic determinants and economic growth in Serbia from 2001 to 2015. Therefore, the research is focused on inflation (INF), monetary aggregate (M3), public expenditures (PE) and foreign direct investment (FDI) as independent variables on gross domestic product (GDP) which is dependent variable in the given model.

Table 1 Review of observed variables

\begin{tabular}{|c|c|c|c|}
\hline Variable & Notation & Calculation & Source \\
\hline Real gross domestic product & GDP & Growth rate & National Bank of Serbia \\
\hline Inflation & INF & Consumer price index & National Bank of Serbia \\
\hline Monetary aggregate 3 & M3 & $\begin{array}{l}\mathrm{M} 2+\text { deposits in foreign } \\
\text { currency }\end{array}$ & Bulletin Public Finances \\
\hline Public expenditures & $\mathrm{PE}$ & $\%$ gross domestic product & $\begin{array}{l}\text { International Monetary } \\
\text { Fund }\end{array}$ \\
\hline Foreign direct investment & FDI & US $\$$ billion & Trading Economics \\
\hline
\end{tabular}

Based on Table 1 it can be seen that real gross domestic product and inflation are calculated by growth rate and consumer price index, while calculation of monetary aggregates is created by the methodology of National Bank of Serbia. Public expenditures and foreign direct investment are determined as a percentage of the gross domestic product by International Monetary Fund and Trading Economics. The model specification can be manifested:

$$
\log \text { GDPt }=\beta_{0}+\beta_{1}(\log \mathrm{INFt})+\beta_{2} \log (\mathrm{M} 3 \mathrm{t})+\beta_{3}(\log \mathrm{PEt})+\beta_{3}(\log \text { FDIt }) \ldots+\text { et }
$$

where

GDP - real gross domestic product, the dependent variable, and proxy for economic growth;

INF - inflation, independent variable;

M3 - monetary aggregate, independent variable;

PE - government expenditures, independent variable;

FDI - foreign direct investment, independent variable;

$\beta-$ the constant term;

$\beta \mathrm{B}-$ the coefficient of the independent variables;

e - the error term of the equation. 


\section{RESULTS}

In the paper, descriptive statistics regression analysis and correlation of observed variables were used, to determine the level of independent variables impact and their relationship with gross domestic product as a dependent variable. Authors used the data for the period 2001 to 2015 , where their values are logarithmically presented.

Table 2 Descriptive statistics of observed variables

\begin{tabular}{cccccc}
\hline Variable & Obs & Mean & Std. Dev. & Min & Max \\
\hline GDP & 15 & 3.107333 & 3.524641 & -3.12 & 9.05 \\
INF & 15 & .8942356 & .4085159 & .1430148 & 1.907089 \\
M3 & 15 & 5.873867 & .3946731 & 5.098346 & 6.300955 \\
PE & 15 & 1.628456 & .0317917 & 1.529045 & 1.663795 \\
FDI & 15 & 9.260291 & .3860589 & 8.249159 & 9.696185 \\
\hline
\end{tabular}

Source: Author's calculation based on SPSS

Descriptive statistics reflects a number of observation and their mean, standard deviation, minimum and maximum values, while authors used their logarithmic values. Table 2 shows that standard deviation is the highest at GDP, while PE had the smallest standard deviation. This means that these components have the highest and lowest variations in the observed group of variables.

Table 3 Regression analysis of observed variables

\begin{tabular}{|c|c|c|c|c|c|c|}
\hline Source & SS & Df & MS & \multicolumn{2}{|c|}{ Number of obs $=$} & 15 \\
\hline Model & 107.340372 & 4 & 26.835093 & \multicolumn{2}{|c|}{$\mathrm{F}(4,10)=$} & 4.03 \\
\hline Residual & 66.5829194 & 10 & 6.65829194 & \multicolumn{2}{|c|}{ Prob $>F=$} & 0.0336 \\
\hline Total & 173.923291 & 14 & 12.4230922 & \multicolumn{2}{|c|}{ R-squared = } & 0.6172 \\
\hline & & & & \multicolumn{2}{|c|}{ Adj R-squared = } & 0.4640 \\
\hline & & & & \multicolumn{2}{|c|}{ Root MSE = } & 2.5804 \\
\hline & & & & \multicolumn{2}{|c|}{ DWstat $=$} & 2.632 \\
\hline GDP & Coef. & Std. Err. & $\mathrm{T}$ & $\mathrm{P}>|\mathrm{t}|$ & \multicolumn{2}{|c|}{ [95\% Conf. Interval] } \\
\hline INF & .9025162 & 2.813815 & 0.32 & 0.755 & -5.367053 & 7.172086 \\
\hline M3 & -9.186444 & 2.881479 & -3.19 & 0.010 & -15.60678 & -2.766108 \\
\hline PE & 11.41743 & 47.39382 & 0.24 & 0.814 & -94.18258 & 117.0174 \\
\hline FDI & 4.01959 & 2.576631 & 1.56 & 0.150 & -1.7215 & 9.760681 \\
\hline _cons & .444854 & 67.25855 & 0.01 & 0.995 & -149.4165 & 150.3062 \\
\hline
\end{tabular}

Based on data from Table, R-square reflects that INF, M3, PE and FDI explain $61.72 \%$ of the variations in GDP. Further, there is a positive effect of dependent variables INF, PE and FDI on GDP, but it is not statistically significant and a negative effect of dependent variable M3 on GDP, which is statistically significant. 
Table 4 Variance Inflation Factor

\begin{tabular}{lcc}
\hline Variable & VIF & $1 /$ VIF \\
\hline PE & 4.77 & 0.209490 \\
INF & 2.78 & 0.359936 \\
M3 & 2.72 & 0.367730 \\
FDI & 2.08 & 0.480644 \\
Mean VIF & 3.09 & \\
\hline \multicolumn{2}{c}{ Source: Author's calculation based on SPSS }
\end{tabular}

Authors used VIF to confirm that there is not a problem of multicollinearity between independent variables. According to data from Table 4, it can be concluded that there is no problem of multicollinearity because the value of VIF is less than the reference value of 10 .

Table 5 Correlations

\begin{tabular}{|c|c|c|c|c|c|c|}
\hline & & GDP & INF & M3 & $\mathrm{PE}$ & FDI \\
\hline \multirow{3}{*}{ GDP } & Pearson Correlation & 1 & .402 & $-.706^{* * *}$ & -.489 & -.246 \\
\hline & Sig. (2-tailed) & & .137 & .003 & .064 & .377 \\
\hline & $\mathrm{N}$ & 15 & 15 & 15 & 15 & 15 \\
\hline \multirow{3}{*}{ INF } & Pearson Correlation & .402 & 1 & $-.562^{*}$ & $-.813^{* *}$ & -.436 \\
\hline & Sig. (2-tailed) & .137 & & .029 & .000 & .104 \\
\hline & $\mathrm{N}$ & 15 & 15 & 15 & 15 & 15 \\
\hline \multirow{3}{*}{ M3 } & Pearson Correlation & $-.706^{* *}$ & $-.562^{*}$ & 1 & $.795^{* *}$ & $.693^{* *}$ \\
\hline & Sig. (2-tailed) & .003 & .029 & & .000 & .004 \\
\hline & $\mathrm{N}$ & 15 & 15 & 15 & 15 & 15 \\
\hline \multirow{3}{*}{$\mathrm{PE}$} & Pearson Correlation & -.489 & $-.813^{* *}$ & $.795^{* *}$ & 1 & $.662^{* *}$ \\
\hline & Sig. (2-tailed) & .064 & .000 & .000 & & .007 \\
\hline & $\mathrm{N}$ & 15 & 15 & 15 & 15 & 15 \\
\hline \multirow{3}{*}{ FDI } & Pearson Correlation & -.246 & -.436 & $.693^{* *}$ & $.662^{* *}$ & 1 \\
\hline & Sig. (2-tailed) & .377 & .104 & .004 & .007 & \\
\hline & $\mathrm{N}$ & 15 & 15 & 15 & 15 & 15 \\
\hline
\end{tabular}

Based on data from Table 5, there is a positive correlation between GDP and INF, where it is not statistically significant. On the other hand, there is a negative correlation between GDP and M3, PE and FDI, which is the nexus between gross domestic product and monetary aggregate statistically significant. Comparing the highest and lowest correlation, it is important to emphasize the relationship between INF and PE where it is negative and statistically significant $(-.813, \mathrm{p}<0.05)$. Also, it recorded the lowest correlation between GDP and INF, but it is not statistically significant $(0.402, \mathrm{p}>0.05)$. 


\section{CONCLUSION}

The paper showed that there is a positive correlation between GDP and INF, but their nexus is not statistically significant. Also, a positive effect of PE and FDI on GDP is determined, but it is not statistically significant and a negative effect of M3 on GDP, which is statistically significant. The novelty is manifested in the fact that in Serbia, there is a small number of studies which are focused on determining the relation between GDP and macroeconomic determinants such as M3, PE, and FDI in this way.

Based on results, monetary indicators INF and M3 have a different impact on GDP. When monetary indicator INF increase, there is an increase in real GDP, while the increase in monetary aggregate M3 causes a drop of GDP. Although there is a high level of correlation between independent variables, there is no problem of multicollinearity and it is determined based on VIF test. The results of correlation found that the highest degree of correlation was recorded between INF and PE, while the lowest degree of correlation represented in relation INF and GDP. Further research could be directed to other countries in the region and thus reflect a similar or completely different trend in their movement and differences among them, if presented.

\section{REFERENCES}

Abbott, A., De Vita, G. (2011). Revisiting the Relationship between Inflation and Growth: A Note on the Role of Exchange Rate Regimes, Economic Issues, 16 (1), 337-352.

Antwi, S. (2013). Impact of macroeconomic factors on economic growth in Ghana: A cointegration analysis, Internation Journal of Academic Research in Accounting, Finance and Management Sciences, 3 (1), 35-45.

Barro, J. (1995). Inflation and Economic Growth, Bank of England Quarterly Bulletin, 166-176.

Beck, W., Wieland, V. (2010). Money in monetary policy design: Monetary cross-checking in the NewKeynesian model, Working paper series, No. 1191.

Boyd, H., Champ, B. (2006). Inflation, Banking and Economic Growth, Federal Reserve Bank of Cleveland Working paper, May 2006, 1-5.

Dotsey, M., Sarte, G. (2000). Inflation Uncertainty and Growth in a Cash-In-Advance Economy, Journal of Monetary Economics, 45 (3), 631-655.

Erbaykal, E., Okuyan, A. (2008). Does Inflation Depress Economic Growth? Evidence from Turkey, International Research Journal of Finance and Economics, (17), 40-48.

Friedman, M., Schwartz, J. (1963). A Monetary History of the United States 1867-1960, Princeton University Press, Princeton.

Friedman, M. (1976). Inflation and Unemployment, Nobel Memorial Lecture, 267-286.

Furtula (2007). Kompatibilnost Narodne banke Srbije sa Evropskom centralnom bankom [Compatibility of the National Bank of Serbia with the European Central Bank]. Bankarstvo (7-8), Udruženje banaka Srbije, 28-47.

Polan, M., Grauwe, P. (2005). Inflation is always and everywhere a monetary phenomenon, Scandinavian Journal of economics, 107 (2), 239-259.

Ghosh, A., Phillips, S. (1988). Warning: Inflation May Be Harmful to Your Growth, International Monetary Fund, IMF Staff Papers, 45(4), 672-710.

Gokal, V., Hanif, S. (2004). Relationship between Inflation and Economic Growth, Economics Department, Reserve Bank of Fiji, Working Paper 04.

Hadžić, M., Barjaktarović, L. (2015). Monetarna ekonomija. [Monetary Economy]. I izdanje, Univerzitet Singidunum, Beograd.

Harris, N., Gillman, M., Matyas, L. (2001). The Negative Inflation-Growth Effect: Theory and Evidence, Melbourne Institute, Working Paper No. 12/01.

Hasanov, F. (2011). Relationship between inflation and economic growth in Azerbaijani economy: Is there any threshold effect? Asian Journal of Business and Management Sciences, 1 (1), 1-11.

Hossain, Ghosh, C., Islam, K. (2012). Inflation and economic growth in Bangladesh, International Refereed Research Journal, 4 (2), 85-92.

Ibarra, R., Trupkin, D. (2015). Reexamining the relationship between inflation and growth: Do institutions matter in developing countries? Economic Modelling, http://dx.doi.org/10.1016/j.econmod.2015.09.011 
Ihsan, I., Anjum, S. (2015). Impact of Money Supply (M2) on GDP of Pakistan, Global Journal of Management and Business Research Finance, 13 (6), 1-8.

International Monetary Fund. (2015). retrieved from: https://www.imf.org/external/pubs/ft/weo/2016/01/weodata/ weoselser.aspx?c=942\&t=1

John, J., Mohanty, D., Chakraborty, B., Das, A. (2011). Inflation Threshold in India: An Empirical Investigation, RBI Working paper 18 .

Khan, S., Senhadji, S. (2001). Threshold Effects in the Relationship between Inflation and Economic Growth, International Monetary Fund, IMF Staff Papers, 48 (1), 1-21.

Kremer, S., Bick, A., Nautz, D. (2012). Inflation and growth: New evidence from a dynamic panel threshold analysis, Empirical Economics, (44), 861-878.

Labus, M. (2011). Kako vratiti novac u monetarnu politku? [Hoe to Return Money in the Monetary Policy?]. Bankarstvo (11-12), Udruženje banaka Srbije, 24-55

Lupu, V. (2012). The Correlation between Inflation and Economic Growth in Romania, Lucrări Ştiinţifice (5), Seria Zootenhie, $359-363$

Mallik, G. and Chowdhury, A. (2001). Inflation and Economic Growth: Evidence from Four South Asian Countries, Asian Pacific Development Journal, (8) 1, 123-135.

Ministry of Finance (2015). Public Finance Bulletin, Republic of Serbia, retrieved from: http://www.mfin.gov. rs/pages/issue.php?id=8528

Mubarik, A. (2005). Inflation and Growth: An Estimate of the Threshold Level of Inflation in Pakistan, SBP-Research Bulletin, (1) 1, 35-44.

Munir, Q., Mansur, K. (2009). Non-Linearity between Inflation Rate and GDP Growth in Malaysia, Economics Bulletin (29) $3,1555-1569$.

National Bank of Serbia (2015). Annual Monetary Policy Report, retrieved from: https://www.nbs.rs/internet/ english/90/90_7/monetary_policy_2015.pdf

Phillips, B. (1987). Time Series Regression with a Unit Root, Econometrica, (55) 2, 271-301.

Quartey, P. (2010). Price Stability and the growth maximizing rate of inflation for Ghana, Modern Economy, (1), 180-194.

Ruzima, M., Veerachamy, P. (2016). Impact of inflation on economic growth: A survey of literature review, International Multidisciplinary Research Journal, Golden Research Thoughts, (5), 10, 1-9.

Saaed, J. (2007). Inflation and Economic Growth in Kuwait: 1985-2005: Evidence from Cointegration and Error Correction Model, Journal of Applied Econometrics and International Development, 7 (1), 203-218.

Snowdon, B., Vane, R. (2005). Modern Macroeconomics: Its Origins, Development and Current state, Edward Elgar, Cheltenham, U.K.

Shuaib, M., Augustine, O., Frank, O. (2014). Impact of Inflation Rate on the Economic Growth in Nigeria, British Journal of Economics, Management \& Trade, 9 (3), 1-11.

Trading Economics (2015). http://www.tradingeconomics.com retrieved from: http://www.tradingeconomics. $\mathrm{com} /$ serbia/foreign-direct-investment-net-inflows-percent-of-gdp-wb-data.html

Wong, Y., Lee, C. (2005). Inflationary threshold effects in the relationship between financial development and economic growth: Evidence from Taiwan and Japan, Journal of Economic Development, 30 (1), 49-69.

\section{MAKROEKONOMSKE DETERMINANTE EKONOMSKOG RASTA U SRBIJI}

Monetarna politika je važan segment ekonomske politike svake zemlje gde inflacija i monetarni agregati predstavljaju značajne komponente. Njihovo kretanje prikazuje trendove u količini novca i nivou cena koje su od velike važnosti za ekonomske prilike u zemlji. Cilj rada je prikazati uticaj makroekonomskih indikatora na realni bruto domaći proizvod. U radu, inflacija (INF), monetarni agregat (M3), javni rashodi (PE) i strane direktne investicije (FDI) su korišćeni kao nezavisne varijable, dok je realni bruto domaći proizvod (GDP) određen kao zavisna varijabla. Rezultati su pokazali da postoji pozitivan odnos između GDP i INF, PE i FDI, ali nije statistički značajan. S druge strane, M3 ima negativan uticaj na GDP i statistički je značajan. Koristeći korelacionu matricu, utvrđena je vrlo visoka korelacija između INF i PE, dokje najniža korelacija zabeležena između GDP i INF.

Ključne reči: bruto domaći proizvod, inflacija, monetarni agregat, javni rashodi, strane direktne investicije, Srbija 